\title{
Workload, Work Pressure and Interpersonal Deviance in Academia: The Mediating Role of Neutralization
}

\author{
Michael Olalekan Adeoti (Corresponding author) \\ $\mathrm{PhD}$ Candidate, Othman Yeop Abdullah Graduate School of Business, Universiti Utara \\ Malaysia, 06010, Sintok, Kedah, Malaysia \\ E-mail: michaelolalekanadeoti@gmail.com/adeoti_michael@oyagsb.uum.edu.my
}

Faridahwati Mohd. Shamsudin

Associate Professor of Human Resource Management

Othman Yeop Abdullah Graduate School of Business, Universiti Utara Malaysia, 06010,

Sintok, Kedah, Malaysia

E-mail: faridah@uum.edu.my

Chong Yen Wan

Senior Lecturer, School of Business Management, Universiti Utara Malaysia, Malaysia

E-mail: chongyen@uum.edu.my

Received: August 21, 2017 Accepted: September 6, 2017 Online published: September 14, 2017

doi:10.5296/ijhrs.v7i4.11730 URL: https://doi.org/10.5296/ijhrs.v7i4.11730

\begin{abstract}
Extant empirical researches on deviant workplace behaviour have concentrated on negative deviant acts directed simultaneously towards both the organizations (organizational) and its members (interpersonal) while others solely focused on deviant behaviours directed at organization and its attributes (organizational deviance). However, no published studies have investigated interpersonal deviance as a main antecedent without considering organizational deviance. Drawing from the theory of neutralization and job demand control model, the present study examined the mediating role of neutralization on the relationships between
\end{abstract}


workload, work pressure and interpersonal deviance. The data was obtained from 356 academics in public universities in Nigeria. Using partial least square structural equation modeling, results revealed that workload and work pressure were significantly related to interpersonal deviance. On the other hand, neutralization significantly mediated the positive relationship between workload and interpersonal deviance. Similarly, neutralization mediated the relationship between work pressure and interpersonal deviance. Conclusively, it is essential to review the existing workloads and working conditions of faculty members in Nigerian public tertiary institutions with a view of minimizing interpersonal deviance.

Keywords: workload, work pressure, neutralization, interpersonal deviance

\section{Introduction}

Researchers have noted that deviant workplace behaviour (DWB) is complex in public establishments compared to private entities (Aquino et al., 2006; Mayhew \& McCarthy, 2005). DWB constitutes a threat to public tertiary institutions in developing countries like Nigeria (Adebisi, Adebisi, \& Arogundade, 2012; Nasir \& Bashir, 2012). DWB is a common and costly phenomenon for organizations (Robinson, 2008). Studies have shown that workplace deviance not only cost organizations substantial amount of money annually, but have negative consequences on employees as well (Lawrence \& Robinson, 2007). Employee deviance is negatively related to profitability and customer satisfaction (Detert, Treviño, Burris, \& Andiappan, 2007).

Generally, teaching is a stressful occupation because of high workload, large class sizes, inadequate salary, and pressure to attract external funding for publications, role conflict, student deviant behaviour and the perceived low status of the profession (Bakker, \& Demerouti, 2016; Hakanen, Bakker \& Schaufeli, 2006). The cumulative effects of high job demands on faculty members' emotions, productivity and attitudes affect their relationships with colleagues and students negatively.

Precisely, this study extends the emerging works on deviant workplace behaviour in many ways. First, we propose a model of mediating processes that links work overload and work pressure to key outcomes in interpersonal deviance. The mediating variable is essential because before employees will engage in DWB, he/she must be convinced that such unethical acts are justified or rationalized. This cognitive process of justification or giving of excuses is what is termed neutralization. Therefore, no matter the employees' perception of workload and work pressure, if such employees cannot submerge their moral compass or convince themselves of the need to behave in an undesired manner, then there cannot be interpersonal deviance. In addition, studies have predicted strong relationship between workload, work pressure and negative behavioural outcomes in organizations (Karasek, 1979; Karasek \& Theorell, 1996; Houston, Meyer \& Paewei, 2006). This strong relationship warrants the introduction of a mediating variable (Baron, \& Kenny, 1986). Hence, we proposed neutralization as a mediator in our research model. Also, we advanced workplace deviance literature by supporting our model with job demand control model and theory of neutralization. 
Furthermore, most studies on DWB have solely focused on multifaceted dimensions of workplace deviance namely interpersonal and organizational deviance (Bennett \& Robinson, 2000; Fagbohungbe, Akinbode, \& Ayodeji, 2012; Lawrence \& Robinson, 2007) while other studies concentrated on organizational deviance (Kura, Shamsudin, \& Chauhan, 2015) but studies which solely focused on interpersonal deviance are non-existent. Regrettably, most noticeable acts of deviance among academics in Nigeria are not directed to the organization or its properties but are directed towards colleagues and /or students, however, studies have neglected this aspect of deviance.

In furtherance to the preceding paragraph, Kura et al. $(2015$, p.2) observed that 'deviant behaviours directed toward individuals within the organization provide opportunity for future research," the current study is heeding the calls for further studies on interpersonal deviance.

\section{Literature Review}

\subsection{Workplace Deviant Behaviour}

Basically, there is positive and negative workplace deviance but the present study focused on negative deviance because of the peculiar challenges in public institutions in Nigeria. Robinson and Bennett (1995) described negative deviant workplace behaviour (DWB) as a voluntary behaviour that breaks organizational norms significantly thereby threatens the well-being of an organization, its workforce or both. Also in the words of Kaplan (1975), it has been described as voluntary behaviours exhibited by employees when they become motivated to violate the expectations placed on them in organizations due to lack of motivation to conform to normative expectations of the social setting they have found themselves. Also, Omar and Sulaiman (2013) described DWB as acts which violate performance standards as set by the organization, thereby resulting in harms to the organization and organizational members.

According to Bennett and Robinson (2000), DWB has two major dimensions namely organizational and interpersonal deviance. In its simplest forms, both forms are judged based on the targeted victims. Those deviant acts whose victims are colleagues and other individuals in the organization are called interpersonal deviance while deviant acts directed at the organization or its properties and production schedules are known as organizational deviance. The focus of the present study is on norm-violating behaviours directed at fellow faculty members, students and other individuals in public HEIs.

In the present study, we conceptualized DWB as any intentional and destructive behaviour exhibited by teaching staff members of HEIs for purpose of personal gains as against morality and which contributes to low standards of education thereby causing harm to the stakeholders.

\subsection{Interpersonal Deviance}

Interpersonal deviance denotes acts that are injurious to members of an organization, such as humiliating colleagues or students, silent treatment, raising voice at students or colleagues, snide treatment, withholding of official information from colleagues, theft from co-workers, 
assigning blame to colleagues, sexual harassment, and gossiping about colleagues (Bennett \& Robinson, 2000). Although DWB has been conceived as a multidimensional concept, we explicitly emphasized the behaviours targeted at an individual and/or student in HEIs in order to ensure parsimony (Arthur, 2011; Kura, Shamsudin, \& Chauhan, 2015). Cases of deviant acts directed at colleagues, and students in HEIs are reported in media on daily basis which signifies that there are more incidences of interpersonal deviance than organizational deviance on campuses. However, in our attempt to focus on interpersonal deviance instead of multifaceted dimensions, we are aware of arguments by Blalock (1979) which postulates that authors cannot attain accuracy, simplicity and generality concurrently. Consequently, our focus is on a specific form of deviance instead of generality.

Victims of interpersonal deviance in the forms of harassment and bullying reported lower levels of organisational commitment, increased absenteeism, lower levels of self-confidence, quitting work or intention to quit and increased on-the-job drug use (Lim \& Teo, 2009; Bartlett \& Bartlett, 2011; Taylor, Bedeian, \& Kluemper, 2012). The main focus of the present study is to examine the mediating role of neutralization on the relationship between workload, work pressure and interpersonal deviance among faculty members.

\subsection{Theory of Neutralization and Job Demand Control Model}

\subsubsection{Theory of neutralization}

Neutralization theory asserts that individuals are free to participate in misbehaviours that they would otherwise believe to be wrong once they can adduce moral reasons for their wrongful acts (Sykes \& Matza, 1957; Lim, 2002). It further states that individuals are largely allegiant (rather than oppositional) to a normative belief system, and must employ justifications to engage in deviant behaviours. Ordinarily, the pressure of work on faculty members may lead to frustration, anger and depression with ability to severe interpersonal relationship with colleagues and/or students. Therefore, if faculty members in Nigerian public HEIs experience excess workload and intense work pressure, they may give moral reasons to engage in interpersonal deviance.

\subsubsection{Job Demand Control}

Karasek's (1979) job demand-control model (JDC) posits that high jobs demand produce a state of normal arousal (increased breathing rate), which enables the body to respond to the demands. However, if there is an environmental constraint, such as low control, the arousal cannot be channelled into an effective coping response. Also, unresolved strain may in turn accumulate and as it builds up can result in anxiety, and depression. Perception of excessive workload and work pressure can result in negative deviant behaviour (Lim, Cortina, \& Magley, 2008). According to the job-stress process model, individuals react negatively to perceived stressors in the workplace including being uncivil to colleagues (Spector, 1998).

\subsection{Workload, Work Pressure and Interpersonal Deviance}

Extant literature revealed two major dimensions of job demands namely academic workload and work pressure (Houston et al., 2006; Karasek \& Theorell, 1996). Academic workload is 
operationalized as the professional efforts a faculty member devotes to activities such as teaching, research, administration, community services, and other academic related tasks while work pressure is conceptualized as the degree to which an academic has to work fast and hard, has a great deal to do, but with too little time (Karasek \& Theorell, 1990).

Work overload and work pressure can result in incivil behaviour (Lim, Cortina, \& Magley, 2008) whenever lecturers perceive high job demands. According to the job-stress process model individuals react negatively to perceived stressors in the workplace by being uncivil (Johnson \& Indvik, 2001). Moreover, as academics try to complete their work tasks quickly, their ability to interact politely with colleagues and students is likely to suffer. On the other hand, if faculty members wish to sustain good effort in the face of growing job demands, it will be tough for them to relate courteously with students and colleagues. Therefore, this inability to interact politely will affect interpersonal relationship in HEIs (Hockey, 1997; Johnson \& Indvik, 2001) and result in interpersonal deviance.

Empirically, Fox, Spector and Miles (2001) found that job demands produced stressor, which is related to both negative emotions and counterproductive work behaviours. Similarly, Omar, Halim, Zainah, and Farhadi (2011) found that positive relationship exists between stress and deviant workplace behaviours. Spector and Fox (2005) developed a stressor-emotion model of workplace deviant behaviour which suggests that deviant behaviours are responses to job demands at work and that perceived high job demands in workplace leads to emotional reactions which can induce deviant behaviours in organizations.

Furthermore, Hakanen et al. (2006) revealed that teachers who perceived work overload and time pressure (high job demands) experienced greater burnout and turnover intentions. Also, Stouten, Baillien, Van den Broeck, Camps, De Witte, and Euwema (2010) demonstrated that higher job demands contributed to a higher likelihood of workplace bullying in organizations. In public HEIs, exposure to excessive work pressure and work overload increases lecturers' perceptions of high job demands, which reduces ability to interact with colleagues and students harmoniously.

Theoretically, Karasek (1979) stated that high job demands were not harmful in themselves, but when accompanied by low decision latitude would result in psychological strain. However, only a few studies have been dedicated to work pressure and such studies found that work pressure is significantly and positively related to workplace bullying and aggression (Stouten et al., 2010; Baillien et al., 2011). On the bases of the above theoretical views and past empirical studies, we hypothesize thus:

H1: Workload will be positively related to interpersonal deviance among faculty members.

H2: Work pressure will be positively related to interpersonal deviance among faculty members.

\subsection{Neutralization}

Theory of neutralization postulates that deviants must neutralize their moral beliefs and standards which can prevent wrong-doing (Sykes \& Matza, 1957). This follows the notion 
that human beings are moral agents, knowing the rights from the bad and for them to engage in the 'bad' behaviours, they must justify such undesired behaviours. Furthermore, Sykes and Matza (1957) and Hinduja (2007) described neutralization techniques to include such statements as 'nobody got hurt by my acts' (denial of victim), 'my colleagues and students did not suffer any harm from my engagement in interpersonal deviant acts' (denial of victim), 'it is not my making, the academic workload and job pressure forced me to act unethically' (denial of responsibility), 'the management of this institution, my colleagues and students are unethical, deviants and wrong-doers as well' (condemnation of the condemners) and 'I hold a responsibility to defend academic staff union in this institution' (appeal to higher loyalties).

2.4.1 Neutralization as a Mediator in the Relationship between Workload, Work Pressure and Interpersonal Deviance

Neutralization stipulates that people can engage in unethical acts provided they can justify their involvement based on reasoning but when the justification is not strong in the sight of the deviants, then, it becomes difficult to partake in deviance. Generally, before employees engage in norm-violating behaviours, neutralization techniques as sets of cognitive response modes must provide valuable explanations (Gruber, \& Schlegelmilch, 2014). In the light of the foregoing, we submit that neutralization techniques bridge the missing link between norm-violating behaviours among lecturers and societal expectations or values.

Empirically, in a study that sought to know the justifications for digital piracy, Yu (2013) found that Asian international students justified digital piracy than American students. The study concluded that neutralization techniques enabled students to engage in digital piracy. Digital piracy was described as an unethical act which involved unauthorized copying of digital audio, software and digital video without express permission from the copy wright holder (Yu, 2012).

Practically, when lecturers adopt neutralization techniques, they would not recognize any wrong in committing interpersonal deviance towards colleagues or students. In other words, neutralization techniques make deviants not to consider their acts as morally reprehensible (Morris \& Higgins, 2009). Similarly, borrowing from disorganization theory, Sykes and Matza's (1957) neutralization theory and deviance literature, consumers have adopted techniques of neutralization to justify non-normative and negative behaviours of both consumers and corporations (De Bock, \& Van Kenhove, 2011). Hence, De Bock and Van Kenhove (2011) found that consumers are less tolerant towards questionable corporate practices compared to similar questionable practices exhibited by the consumers. In other words, it is easier for consumers to justify their own deviant acts using neutralization techniques while consumers condemn organizations easily.

Similarly, high workload and pressure can make academics to engage in interpersonal deviance because they will seek alternatives to show their dissatisfaction. In addition, job-related stress and pressure can make employees to become frustrated, impatient, irritated and such emotions can lead to variety of deviant behaviours. Hence, positive relationship is predicted between neutralization and multiple forms of deviance (Lim, 2002). 


\section{Macrothink}

International Journal of Human Resource Studies

ISSN 2162-3058

2017, Vol. 7, No. 4

Therefore, drawing from neutralization theory (Sykes \& Matza, 1957), the researchers posit that it is reasonable for lecturers who perceived stressful workload and work pressure in HEIs to engage in self-justifications before engaging in interpersonal deviance. In this case, academics may say 'the management of this institution, my colleagues and students are unethical, deviants and wrong-doers as well' (condemnation of the condemners). Also, faculty members may say 'interpersonal deviance and conflicts are normal things among people in organizations' (claim of normalcy). Based on theoretical perspectives and empirical submissions, the following hypotheses emerged:

H3: Neutralization mediates the relationship between workload and interpersonal deviance among faculty members.

H4: Neutralization mediates the relationship between work pressure and interpersonal deviance among faculty members.

The relationship between work overload, work pressure, and interpersonal deviance with neutralization as a mediating variable is depicted in Figure 1.

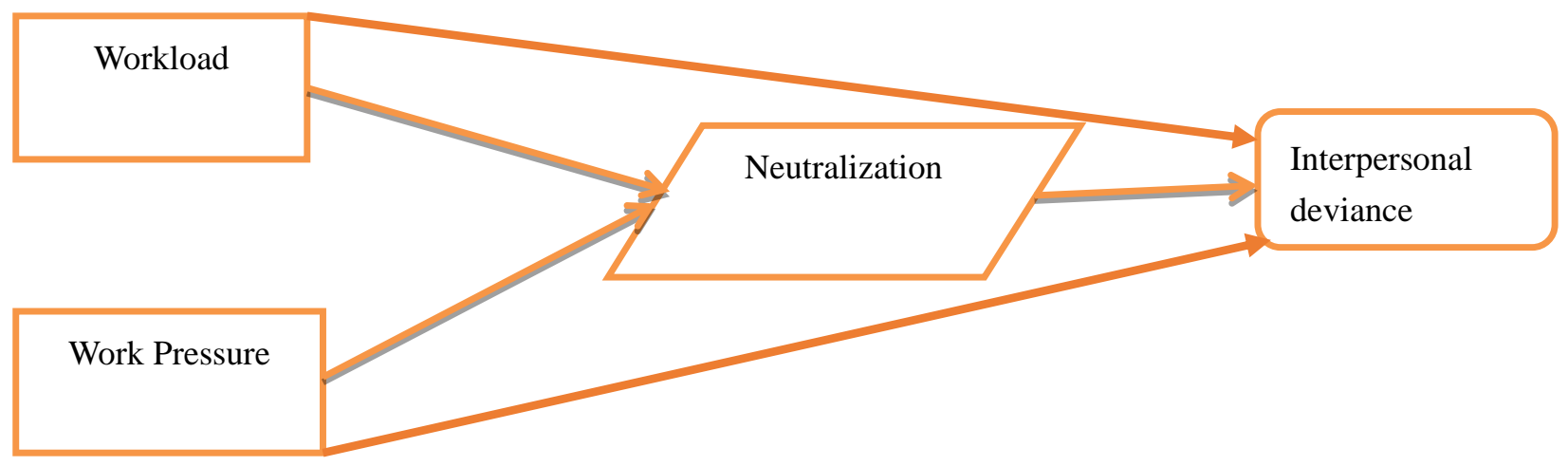

Figure 1. Theoretical Framework

The theoretical framework is connected by job-demand control model, neutralization theory and past empirical studies.

\section{Methodology}

\subsection{Research Design}

We adopted a cross-sectional research design. Self-administered questionnaire was used to collect data from 356 full time faculty members in Nigerian public higher educational institutions (HEIs). Statistical packages for social sciences (SPSS version 24) was used for initial data screening while partial least square structural equation modelling (PLS-SEM 3.2) was employed for data analysis.

\subsection{Participants and Data Collection}

The sample is made up of 356 teaching staff of public universities in Nigeria. The choice of 
public HEIs is justified because negative deviance is higher in Nigerian public HEIs than private HEIs (Geidam, Njoku, \& Bako, 2011; Makinde, 2013) In terms of gender, 274 participants were males (77\% of the participants) while 82 participants which represented $23 \%$ were females. Educationally, $29.2 \%$ of the participants were first degree holders, $45.2 \%$ possessed Masters' degrees while $25.6 \%$ of the participants were doctorate degree holders. About $70 \%$ of the participants have spent 6 years and above on the job. In terms of age, 39\% of the participants aged 41-50 years, 34\% aged 31-40 years, $21.1 \%$ of the participants aged 50 years and above while $5.9 \%$ of the participants aged $21-30$ years.

\subsection{Measures/Instruments}

This study adapted survey instruments to obtain data from the participants.

a. Interpersonal deviance

Interpersonal deviance was assessed with 8 -item $(\alpha=0.78)$ adapted to suit Nigerian context. The original scale was developed by Bennett and Robinson (2000). The validation procedures recommended by Polit and Beck (2006) were observed. All items were scored on a 5-point Likert scale ( $1=$ never; 2 = rarely; $3=$ sometimes; $4=$ often; $5=$ always $)$.

b. Workload

Workload was assessed with 8 items ( $\alpha=0.74$ to 0.78 ) adapted from and Houston, Meyer and Paewei (2006) job demands scale. Participants were asked to indicate their perception of workload on a 5 -point Likert scale ( $1=$ strongly disagree to $5=$ strongly agree).

c. Work pressure (WP)

WP was assessed with 5 items ( $\alpha=0.73$ to 0.85 ) adapted from Karasek and Theorell's (1990) scale. All participants were requested to specify their level of agreement on a 5-point Likert scale $(1=$ strongly disagree to $5=$ strongly agree $)$. The original items were rephrased from question form to statement form.

\section{d. Neutralization}

Neutralization was measured with 6 items $(\alpha=0.861)$ adapted from Rogers and Buffalo (1974) neutralization scale. All participants were requested to indicate their level of agreement on a 5-point Likert scale ( $1=$ strongly disagree; $2=$ Disagree; $3=$ neither disagree nor agree; 4 = Agree; 5 = strongly agree).

\section{g. Demographics}

Participants responded to demographic variables by choosing from the alternatives provided in the scale covering age, gender, highest educational qualifications, length of service and marital status.

\subsection{Analysis}

We employed SmartPLS-SEM 3.2 as a tool of analysis notwithstanding the weaknesses of partial least square structural equation modeling. PLS-SEM has the benefit of estimating the 
correlations among structural and measurement models concurrently (Chin, Newsted, \& Marcolin, 2003). Second, SmartPLS helps users to test a mediating effect using Preacher and Hayes's $(2004,2008)$ bootstrapping techniques of estimating indirect effects in mediation models. Third, the present study has a complex model (Hair, Ringle, and Sarstedt, 2013).

\section{Results and Findings}

\subsection{Data Screening}

In order to overcome common method variance (CMV), we observed both procedural and statistical remedies to lessen the impacts of CMV as recommended by Podsakoff et al. (2012). According to Hair, Ringle and Sarstedt (2011), multicollinearity is not a problem in the present study because VIF values are less than 5 (O'Brien, 2007; Rogerson, 2001) and tolerance values for all variables range from 0.425 to .837 , indicating higher values than the threshold 0.20. Additionally, the normality test revealed that none of the items in the dataset has a skewness and kurtosis statistics above \pm 3 and \pm 10 respectively. After satisfying all preliminary screening conditions and all statistics fit within recommended parameters, we analyzed both measurement and structural models as shown in subsequent sub-sections:

\subsection{Results of Measurement Model}

First, we assessed individual item reliability and construct reliability (internal consistency reliability) using composite reliability index (CRI) because CRI has been proved to be more superior to cronbach's alpha (Hair, Sarstedt, Ringle, \& Mena, 2012). Table 1 revealed that the CRI of each construct ranged from 0.883 to 0.975 , exceeding the minimum acceptable level of 0.70 (Bagozzi \& Yi, 1988). In terms of individual item reliability, Table 1 and Figure 1 showed items with loadings 0.70 and above (Hair et al., 2014).

Table 1. Outer loadings, composite reliability (CR), average variance extracted (AVE) (Measurement model)

\begin{tabular}{lccc}
\hline Constructs and Indicators & Loadings & $\begin{array}{c}\text { Composite } \\
\text { Reliability }\end{array}$ & AVE \\
\hline Workload & & 0.903 & 0.652 \\
WL01 & 0.881 & & \\
WL02 & 0.885 & & \\
WL03 & 0.752 & & \\
WL05 & 0.771 & & \\
WL06 & 0.735 & & \\
Work pressure & & 0.716 \\
WP01 & 0.901 & & \\
WP02 & 0.781 & & \\
WP04 & 0.851 & & \\
Neutralization & & 0.865 \\
NT01 & 0.922 & & \\
NT02 & 0.865 & &
\end{tabular}




\section{Macrothink}

International Journal of Human Resource Studies

ISSN 2162-3058 2017, Vol. 7, No. 4

$\begin{array}{ll}\text { NT03 } & 0.955 \\ \text { NT04 } & 0.944 \\ \text { NT05 } & 0.954 \\ \text { NT06 } & 0.937\end{array}$

Interpersonal deviance

0.948

0.819

ID01

0.830

ID02

0.926

ID03

0.928

ID04

0.933

Furthermore, Table 1 shows that average variance extracted (AVE) to ascertain convergent validity in the present study. According to Chin (1998a), the AVE for each latent construct should not be less than 0.50 . A look at Table 1 revealed that the AVE values ranged from 0.652 to 0.865 , indicating adequate convergent validity.

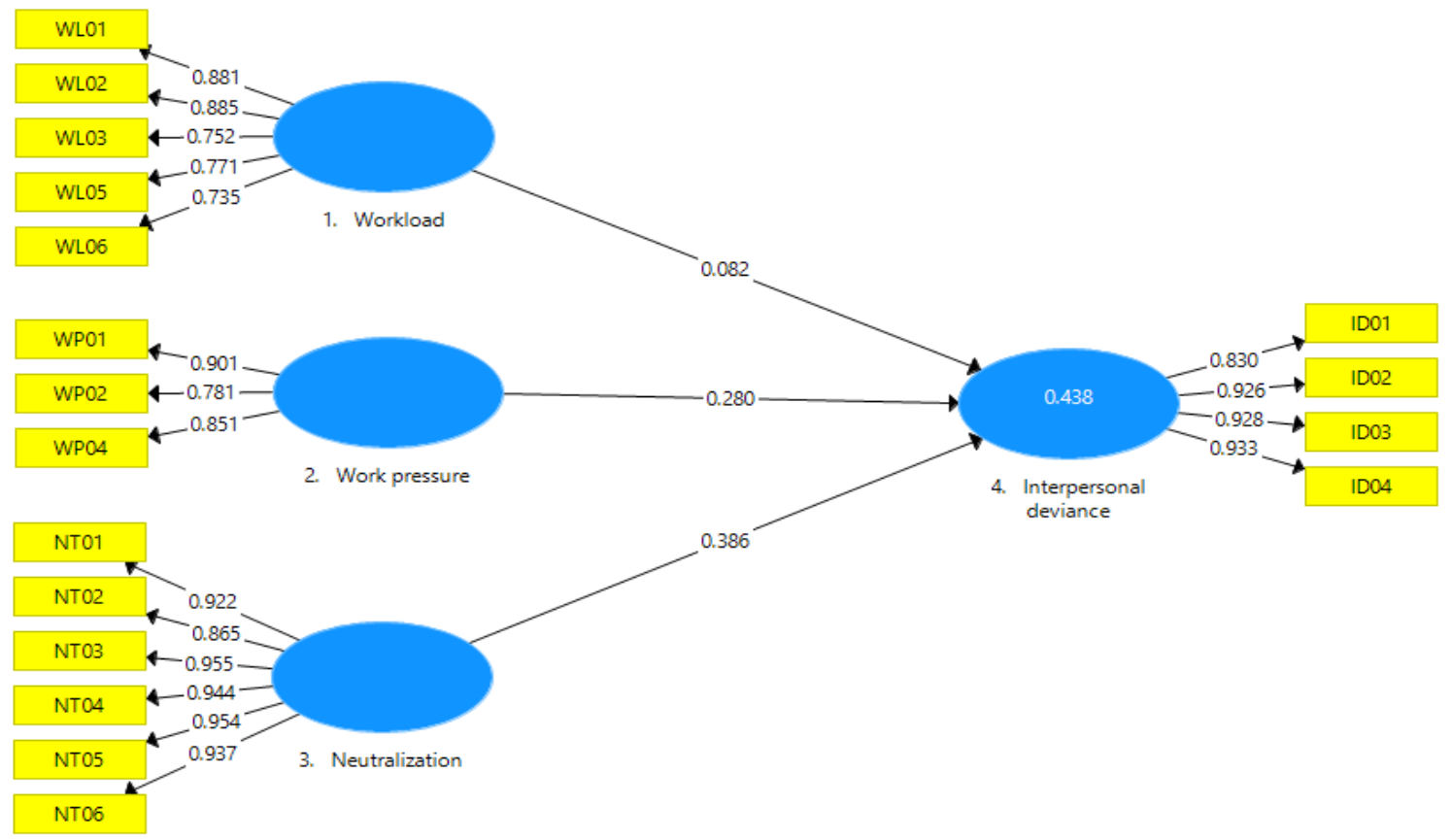

Figure 2. Measurement model graph

Next, we analyzed discriminant validity (Table 2) by comparing the square roots of AVE for each latent construct with the correlations among latent constructs and our results suggest satisfactory discriminant validity (Fornell \& Larcker, 1981). 


\section{Macrothink}

Table 2. Discriminant Validity (Fornell-Larcker Criterion)

\begin{tabular}{llcccc}
\hline & & $\mathbf{1}$ & $\mathbf{2}$ & $\mathbf{3}$ & $\mathbf{4}$ \\
\hline 1. & Workload & $\mathbf{0 . 8 0 7}$ & & & \\
2. & Work pressure & 0.709 & $\mathbf{0 . 8 4 6}$ & & \\
3. & Neutralization & 0.624 & 0.604 & $\mathbf{0 . 9 3 0}$ & \\
4. & Interpersonal deviance & 0.523 & 0.572 & 0.607 & $\mathbf{0 . 9 0 5}$ \\
\hline
\end{tabular}

Furthermore, in order to cross-examine the results of Fornell-Larker criterion, we appraised discriminant validity by computing Heterotrait-Monotrait ratio (HTMT). Table 3 presents result of discriminant validity using HTMT.

Table 3. Discriminant Validity - (Heterotrait-Monotrait Ratio (HTMT)

\begin{tabular}{llcccc}
\hline & & $\mathbf{1}$ & $\mathbf{2}$ & $\mathbf{3}$ & $\mathbf{4}$ \\
\hline 1. & Workload & & & & \\
2. & Work pressure & 0.828 & & & \\
3. & Neutralization & 0.670 & 0.676 & & \\
4. & Interpersonal deviance & 0.577 & 0.651 & 0.638 & \\
\hline
\end{tabular}

Table 3 revealed that the highest correlation is between workload and work pressure 0.828 . All correlation values obtained are less than the cut-off value of 0.850 which confirms an acceptable level of HTMT in assessing discriminant validity (Clark \& Watson, 1995; Henseler, Ringle, \& Sarstedt, 2015). Also, all the parameters used to judge the validity and reliability of our constructs proved satisfactory. Next sub-section describes the structural model of this study.

\subsection{Structural Model}

We employed bootstrapping techniques of estimating indirect effects in mediation models as suggested by Hayes (2013), as well as Preacher and Hayes (2004, 2008). This procedure provides "higher levels of statistical power compared with the Sobel's test" (Spector \& Jex, 1998, p. 223). First, we evaluated the path coefficients by testing the direct relationship between workload, work pressure and interpersonal deviance $(\mathrm{H} 1, \mathrm{H} 2)$.

Table 4. Structural model results (Hypotheses testing for direct effect)

\begin{tabular}{clccccc}
\hline Hypotheses & Relations & Beta & SE & $\boldsymbol{t}$-value & 95\% CI & Findings \\
\hline H1 & Workload $\rightarrow$ Interpersonal deviance & 0.234 & 0.072 & 3.279 & {$[0.127 ; 0.365]$} & Supported \\
$\mathbf{H 2}$ & Work pressure $\rightarrow$ Interpersonal & 0.406 & 0.086 & 4.717 & {$[0.248 ; 0.537]$} & Supported \\
& deviance & & & & & \\
\hline & $R^{2}$ & ID & & & & \\
& $Q^{2}$ & $35.5 \%$ & & & & \\
& SRMR & 0.270 & & & & \\
\end{tabular}




\section{Macrothink}

International Journal of Human Resource Studies

ISSN 2162-3058

2017, Vol. 7, No. 4

Based on results in Table 4, H1 and H2 were both supported. Specifically, the results for Hypothesis 1 revealed a significant positive relationship between perceived workload and interpersonal deviance $(\beta=0.234 ; \mathrm{t}=3.279)$ and at $95 \%$ confidence interval $(\mathrm{CI})$, both lower and upper values were positive $(0.127 ; 0.365)$, indicating significant support for Hypothesis 1 . Also, the predicted positive relationship between perceived work pressure and interpersonal deviance showed a significant positive relationship $(\beta=0.406 ; \mathrm{t}=4.717)$. Additionally, both lower and upper level values were significantly positive at $95 \%$ confidence $(0.248 ; 0.537)$, which suggests strong support for Hypothesis 2.

As shown in Table 4, SmartPLS-SEM 3.0 can estimate coefficient of determination $\left(R^{2}\right)$ and predictive relevance $\left(Q^{2}\right)$ simultaneously. Stone-Geisser test of predictive relevance- $\mathrm{Q}^{2}$ (Geisser, 1974; Stone, 1974) was observed after running the blindfolding procedure (Chin, 1998 b; Spector \& Jex, 1998). The $R^{2}$ value for the direct effect is 0.36 (see Table 4 and Figure 3), which implies that the model explained $36 \%$ of the total variance in interpersonal deviance. Also, the $Q^{2}$ value for interpersonal deviance was 0.270 (Table 4). The $Q^{2}$ value exceeded zero, which suggests satisfactory predictive relevance of the model (Chin, 1998a). We measured goodness of fit using standardized root mean residual (SRMR). Our model recorded SRMR value of 0.067 , which is less than 0.10 signifying a satisfactory value for goodness of fit (Henseler et al., 2014).

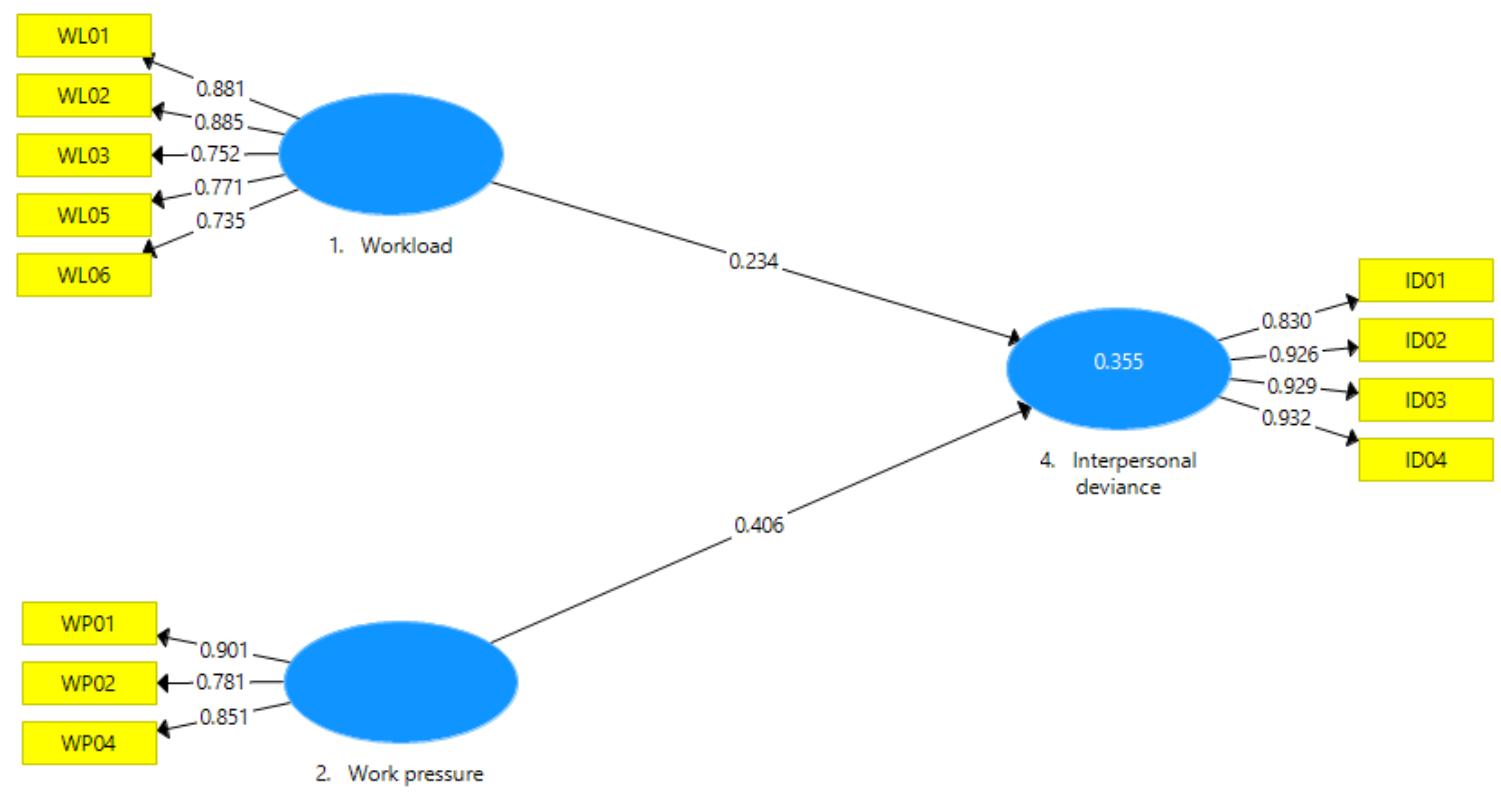

Figure 3. Structural model graph (Direct Effect $R^{2}$ ) 


\section{Macrothink}

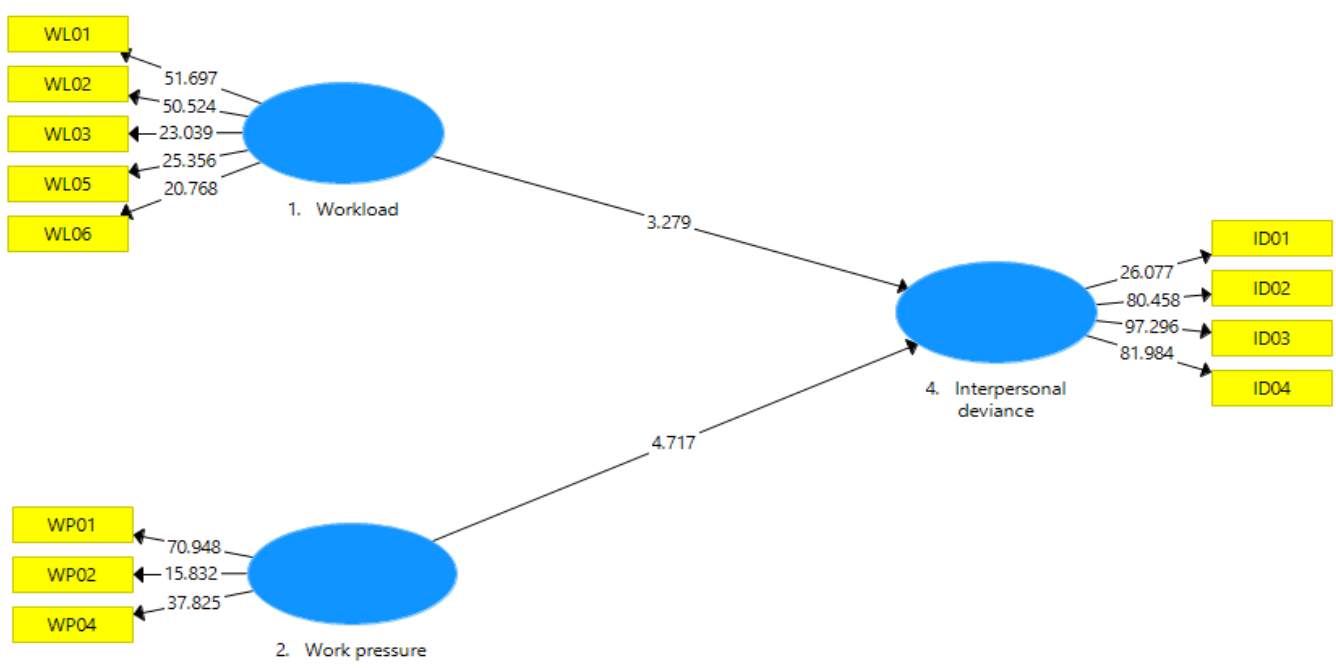

Figure 4. Structural model results (Direct Effect)

Furthermore, when a mediator was incorporated in the PLS path model, we applied the standard bootstrapping procedure with a number of 5000 bootstrap samples and 356 cases to assess significance of the path coefficients (Spector \& Jex, 1998; Henseler et al., 2012). The results in Table 5 showed that the indirect effect of perceived workload on interpersonal deviance via neutralization (mediator) was found to be significant $(\beta=0.153 ; \mathrm{t}=4.777)$ and predicted interpersonal deviance in positive direction (H3). In addition, at 95\% confidence interval, both lower and upper level values were positive $(0.101 ; 0.205)$. This implies that Hypothesis 3 is supported. Similarly, the positive relationship between perceived work pressure and interpersonal deviance was mediated significantly by neutralization $(\beta=0.124$; $\mathrm{t}=3.475$ ) giving credence to Hypothesis 4 . Also, an attempt was made to test Hypothesis 4 at 95\% confidence interval and the results yielded positive values for lower and upper level (0.070; 0.187), which signifies acceptance of Hypothesis 4.

Table 5. Structural model results (mediation test- indirect effect)

\begin{tabular}{clccccc}
\hline Hypotheses & Relations & Beta & SE & $\boldsymbol{t}$-value & 95\% CI & Findings \\
\hline H3 & Workload $\rightarrow$ Interp. Deviance & 0.153 & 0.032 & 4.777 & {$[0.101 ; 0.205]$} & Supported \\
H4 & Work pressure $\rightarrow$ Interp. Deviance & 0.124 & 0.036 & 3.475 & {$[0.070 ; 0.187]$} & Supported \\
\hline & & ID & & & & \\
& $R^{2}$ & $44 \%$ & & & & \\
& $Q^{2}$ & 0.332 & & & & \\
& SRMR & 0.055 & & & & \\
\end{tabular}

As shown in Table 5, the coefficient of determination (R2) was 44\% (.44), which indicates that the indirect effect model explained $44 \%$ of the total variance in interpersonal deviance. After running the blindfolding procedure (Chin, 1998), the results revealed $\mathrm{Q}^{2}$ value for interpersonal deviance 0.332 . Statistically, all values were greater than zero, thus, indicating acceptable predictive relevance of the indirect model (Chin, 1998). 


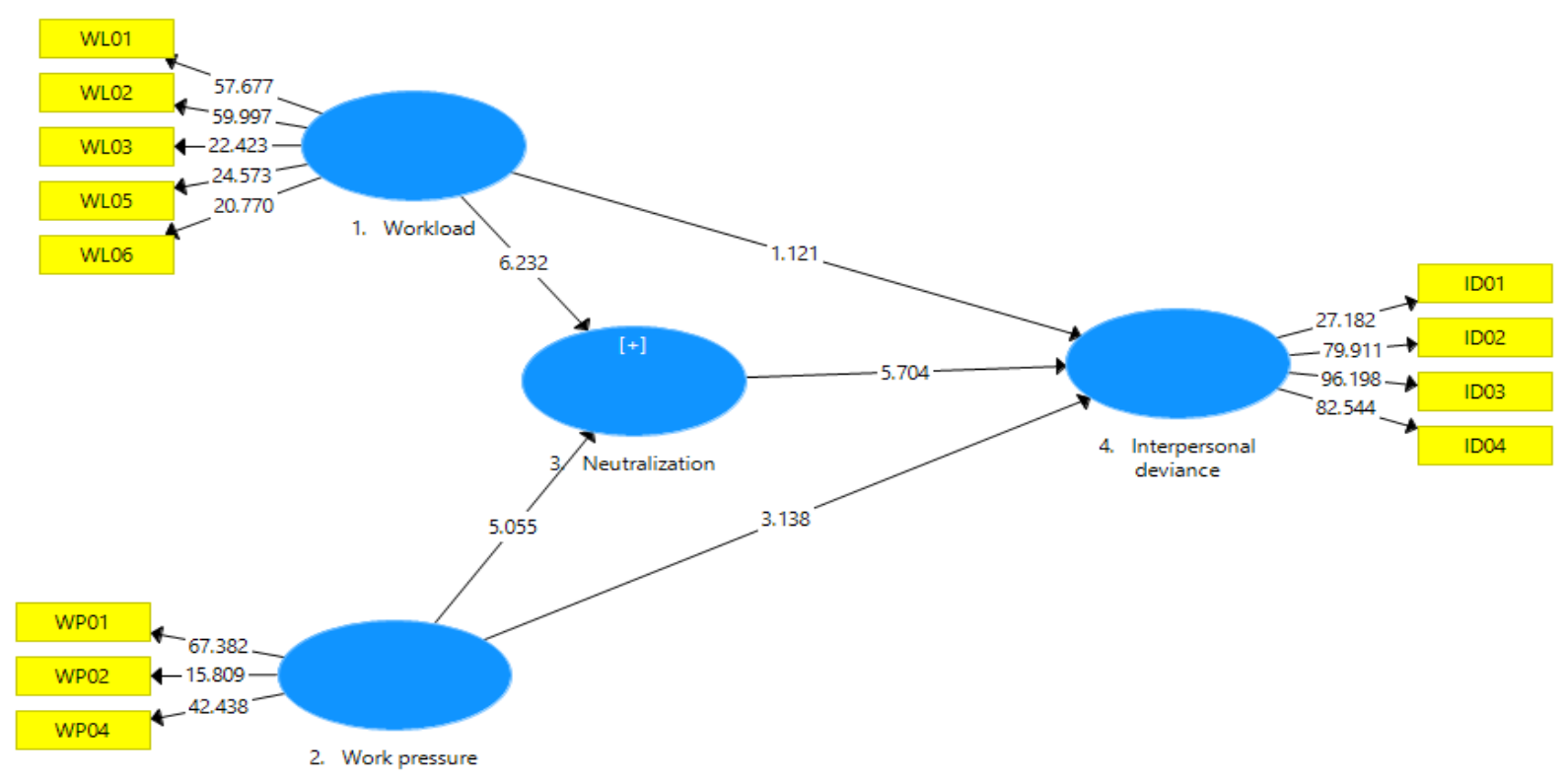

Figure 5. Structural model results (Indirect effect)

Figure 5 showed a significant positive relationship between workload and neutralization, a positive relationship between work pressure and neutralization and significant mediating effect of neutralization on the constructs. These values justified the introduction of a mediating variable in the model (Baron \& Kenny, 1986).

\section{Discussion and Conclusion}

This study set-out to examine the mediating role of neutralization on the relationship between workload and interpersonal deviance on one hand and to determine the mediating effect of neutralization on the relationship between work pressure and interpersonal deviance among faculty members in Nigeria's universities. Results indicated that neutralization significantly mediated the relationship between workload and interpersonal deviance in a positive direction at $95 \%$ confidence interval. Furthermore, neutralization mediated significantly the positive relationship between work pressure and interpersonal deviance.

One plausible explanation for these results is that the presence of neutralization enables faculty members to justify their involvement in interpersonal deviance, especially when they experience high workload and excessive work pressure over a long period. This argument is supported by theory of neutralization which posits that deviants need to neutralize their moral beliefs and values that would normally prevent wrong-doing. The essence is to enable deviants to present themselves acceptably to the society and overcome guilt feelings (Sykes \& Matza, 1957; Hinduja, 2007).

Empirically, there is an agreement between our results and neutralization theory and we have contributed to knowledge by testing and confirming neutralization as a mediator. Extant literature found that cyber loafers used neutralization to justify their engagement in cyberloafing when they experienced organizational injustice (Lim, 2002). Similarly, Yu (2013) 
found that Asian international students adopted neutralization techniques to justify their role in digital piracy while another study found that consumers employed different neutralization techniques to justify shoplifting (De Bock \& Van Kenhove, 2011). Additionally, the results of the direct effect model shown in Table 4 agreed with past studies which found positive relationship between high workload and work pressure and interpersonal conflicts/deviance in different contexts (Karasek \& Theorell, 1990; Houston, Meyer \& Paewei, 2006; Jovanovich, Lazaridis, \& Stefanović, 2006). Specifically, high job demands are perceived to be a problem in jobs with high pressure and low pay, such as teaching.

In conclusion, the present study has proved that neutralization mediated the relationship between perceived workload, work pressure and interpersonal deviance among lecturers in public universities in Nigeria. The results showed that both workload and work pressure are positively related to neutralization, which in turn predicted interpersonal deviance in a positive way at $95 \%$ confidence interval. Accordingly, the present study proves that neutralization techniques are fundamental mechanisms through which perceived work pressure and workload can predict interpersonal deviance. Therefore, it is essential to review the existing workloads and working conditions of faculty members in Nigerian public universities with a view of minimizing interpersonal deviance.

\section{Implications for Research and Practice}

The present study contributed to the existing literature on organizational behaviour and particularly, deviant workplace behaviour (DWB). The researchers are of the view that most existing literature have western settings and application of their findings in Africa, especially Nigeria is limited due to differences in culture and values. We proposed and validated a model which reflects realities in Nigerian public institutions, a sector which has been grossly under-researched. The present study adds value to DWB literature by testing a mediating variable on the constructs. The results of the mediation indicated that Nigerian lecturers in public HEIs are experiencing excess workload and severe work pressure which have led to their involvement in interpersonal deviance.

The major theoretical contribution of this study is the enhancement of neutralization theory and job demand control model (JDC model) in explaining interpersonal deviance among faculty members in Nigerian public HEIs. Extant literature revealed that neutralization theory was originally used to predict adolescent delinquency but the present study proved that the same theory can be used to predict deviance among adult participants. Also, available studies indicated that JDC model has been used in stress-related studies but we extended its usage to predict interpersonal deviance, thereby extending frontiers of knowledge.

In furtherance to the above, understanding the predictors of interpersonal deviance as discussed in this study have practical implications. For example, our results suggest that management of HEIs can minimize incidence of interpersonal deviance by taking holistic review of the existing workload of academics and improve physical working conditions in institutions. It is evident that lecturers in public universities in Nigeria are experiencing high job demands. Therefore, the state and federal ministries of education and administrators of HEIs need to identify proactively the lecturers' perceptions on teaching, research, community 
service and other administrative responsibilities to foster harmonious relationships in HEIs. Relatedly, Spector and Fox (2005) developed a stressor-emotion model of workplace deviant behaviour that suggests deviant behaviours are responses to job demands at work. According to Spector and Fox's model, perceived high job demands in workplace can lead to emotional reactions and as a result can induce deviant behaviours in organizations. Therefore, there is need to reduce job stressors in form of job demands in order to minimize interpersonal deviance. Also, the management needs to show empathy towards the faculty members in order to discourage application of neutralization techniques.

\section{Limitations and Future Research}

The following constraints and guides for future researchers should be considered when interpreting the results of the present study. First, the cross-sectional nature of the present study implies that the findings have limited generalization. Hence, this study needs to be replicated using longitudinal research to allow for causal inferences. Secondly, the sample was drawn from lecturers in public universities in Nigeria. Therefore, we suggest that future researchers should include faculty members in private HEIs in order to generalize their findings to the whole HEIs in Nigeria. Thirdly, neutralization may not be the only mediating variable that may be introduced in the relationship between workload, work pressure and interpersonal deviance. Therefore, other variables such as age, workplace spirituality and length of service should be considered by future researchers. Finally, we assessed interpersonal deviance using self-report measures. Self-reports may generate common method variance and social desirability bias (Podsakoff et al., 2012; Dodaj, 2012). Although, we took precautions to reduce bias by removing ambiguities in items, confidentiality and anonymity were observed and we computed Harman's one factor to test CMV (Podsakoff et al., 2012). However, future researchers should consider peer-rating in order to control common method variance.

Lastly, our focus on interpersonal deviance opens avenues for coming researchers on DWB to study deviant acts directed towards the organization and organizational properties (organizational deviance).

\section{References}

Adebisi, P. A., Adebisi, O. S., \& Arogundade, K. K. (2012). Academic corruption and the challenge of unemployable graduates in Nigeria: Implications for entrepreneurship development and economic growth. Journal of Commerce, 4(1), 1-12.

Akinbode, G. A., \& Fagbohungbe, B. O. (2011). Gender, tenure and organisational factors as predictors of job involvement among Nigerian workers. Gender and Behaviour, 9(2), 4005-4038. https://doi.org/10.4314/gab.v9i2.72175

Aquino, K., Tripp, T. M., \& Bies, R. J. (2006). Getting even or moving on? Power, procedural justice, and types of offense as predictors of revenge, forgiveness, reconciliation, and avoidance in organizations. Journal of Applied Psychology, 91(3), 653-668. https://doi.org/10.1037/0021-9010.91.3.653 
Arthur, J. B. (2011). Do HR system characteristics affect the frequency of interpersonal deviance in organizations? The role of team autonomy and internal labour market practices. Industrial Relations: A Journal of Economy and Society, 50, 30-56. https://doi.org/10.1111/j.1468-232X.2010.00624.x

Bagozzi, R. P., \& Yi, Y. (1988). On the evaluation of structural equation models. Journal of the Academy of Marketing Science, 16(1), 74-94. https://doi.org/10.1007/BF02723327

Baillien, E., De Cuyper, N., \& De Witte, H. (2011). Job autonomy and workload as antecedents of workplace bullying: A two-wave test of Karasek's job demand control model for targets and perpetrators. Journal of Occupational and Organizational Psychology, 84(1), 191-208. https://doi.org/10.1348/096317910X508371

Bakker, A. B., \& Demerouti, E. (2007). The job demands-resources model: State of the art. Journal of Managerial Psychology, 309-328. https://doi.org/10.1108/02683940710733115

Bakker, A. B., \& Demerouti, E. (2016). Job demands-resources theory: Taking stock and looking forward. In Peter Y. Chen and Cary L. Cooper (Eds.). Work and wellbeing: $a$ complete reference guide, Volume III. John Wiley \& Sons, Inc. https://doi.org/10.1002/9781118539415.wbwell019

Baron, R. M., \& Kenny, D. A. (1986). The moderator-mediator variable distinction in social psychological research: Conceptual, strategic, and statistical considerations. Journal of $\begin{array}{llll}\text { Personality and Social } & \text { Psychology, } & \text { 51(6), }\end{array}$ https://doi.org/10.1037/0022-3514.51.6.1173

Bartlett, J. E., \& Bartlett, M. E. (2011). Workplace Bullying: An Integrative Literature Review. Advances in Developing Human Resources, 13(1), 69-84. https://doi.org/10.1177/1523422311410651

Bennett, R. J., \& Robinson, S. L. (2000). Development of a measure of workplace deviance. Journal of Applied Psychology, 85, 349-360. https://doi.org/10.1037/0021-9010.85.3.349

Berry, C. M., Ones, D. S., \& Sackett, P. R. (2007). Interpersonal deviance, organizational deviance, and their common correlates: a review and meta-analysis. Journal of Applied Psychology, 92(2),

410-424. https://doi.org/10.1037/0021-9010.92.2.410https://doi.org/10.1037/0021-9010.92.2.410

Blalock, H. M. (1979). The presidential address: Measurement and conceptualization problems: the major obstacle to integrating theory and research. American Sociological Review, 44, 881-894. https://doi.org/10.2307/2094714

Chen, P.Y., \& Spector, P.E. (1992). Relationships of work stressors with aggression, withdrawal, theft and substance use: an exploratory study. Journal of Occupational and Organizational Psychology, 65, 177-194. https://doi.org/10.1111/j.2044-8325.1992.tb00495.x

Chin, W. W. (1998b). The partial least squares approach for structural equation modeling. In George A. Marcoulides (Ed.), Modern Methods for Business Research (pp.295-336). Mahwah, 
NJ: Lawrence Erlbaum Associates,

Chin, W. W., Marcolin, B. L., \& Newsted, P. R. (2003). A partial least squares latent variable modeling approach for measuring interaction effects: Results from a Monte Carlo simulation study and an electronic-mail emotion/adoption study. Information Systems Research, 14, 189-217. https://doi.org/10.1287/isre.14.2.189.16018

Chin, W.W. (1998a). Issues and opinion on structural equation modeling. MIS Quarterly, 22, 1 , VII-XVI

Clark, LA, \& Watson, D. (1995). Constructing validity: Basic issues in objective scale development. Psychological Assessment, 7(3), 309-319. doi: https://doi.org/10.1037/1040-3590.7.3.309

Cortina, L. M., \& Magley, V. J. (2009). Patterns and profiles of response to incivility in the workplace. Journal of Occupational Health Psychology, 14(3), 272-288. https://doi.org/10.1037/a0014934

De Bock, T., \& Van Kenhove, P. (2011). Double standards: The role of techniques of neutralization. Journal of Business Ethics, 99(2), 283-296. https://doi.org/10.1007/s10551-010-0654-3

Detert, J. R., Treviño, L. K., Burris, E. R., \& Andiappan, M. (2007). Managerial modes of influence and counter-productivity in organizations: A longitudinal business-unit-level investigation. Journal of Applied Psychology, 92(4), 993- 1005. https://doi.org/10.1037/0021-9010.92.4.993

Dodaj, A. (2012). Social desirability and self-reports: Testing a content and response-style model of socially desirable responding. Europe's Journal of Psychology, 8, 651-666. https://doi.org/10.5964/ejop.v8i4.462

Fagbohungbe, B. O., Akinbode, G. A., \& Ayodeji, F. (2012). Organizational determinants of workplace deviant behaviours: An empirical analysis in Nigeria. International Journal of Business and Management, 7(5), 207-221. https://doi.org/10.5539/ijbm.v7n5p207

Fallon, J. D., Avis, J. M., Kudisch, J. D., Gornet, T. P., \& Frost, A. (2000). Conscientiousness as a predictor of productive and counterproductive behaviors. Journal of Business and Psychology, 15(2), 339-349. https://doi.org/10.1023/A:1007880203956

Federal Government of Nigeria (2012). Report of Committee on needs assessment of Nigerian public universities

Fornell, C., \& Larcker, D. F. (1981). Evaluating structural equation models with unobservable and measurement error. Journal of Marketing Research, 18, 39-50. https://doi.org/10.2307/3151312

Fox, S., Spector, P.E. \& Miles, D. (2001). Counterproductive work behaviour (CWB) in response to job stressors and organizational justice: some mediator and moderator tests for autonomy and emotions. Journal of Vocational Behaviour, 59, 291-309. 
https://doi.org/10.1006/jvbe.2001.1803

Geisser, S. (1974). A predictive approach to the random effect model. Biometrika, 61, 101-107. https://doi.org/10.1093/biomet/61.1.101

Gruber, V., \& Schlegelmilch, B. B. (2014). How techniques of neutralization legitimize norm-and attitude-inconsistent consumer behavior. Journal of Business Ethics, 121(1), 29-45. https://doi.org/10.1007/s10551-013-1667-5

Hair, J. F., Ringle, C. M., \& Sarstedt, M. (2011). PLS-SEM: Indeed a silver bullet. Journal of Marketing Theory and Practice, 18, 139-152. https://doi.org/10.2753/MTP1069-6679190202

Hair, J. F., Ringle, C. M., \& Sarstedt, M. (2013). Partial least squares structural equation modeling: Rigorous applications, better results and higher acceptance. Long Range Planning, 46(1-2), 1-12. https://doi.org/10.1016/j.lrp.2013.01.001

Hair, J. F., Sarstedt, M., Ringle, C. M., \& Mena, J. A. (2012). An assessment of the use of partial least squares structural equation modeling in marketing research. Journal of the Academy of Marketing Science, 40, 414-433. https://doi.org/10.1007/s11747-011-0261-6

Hair, J.F., Sarstedt, M., Hopkins, L. \& Kuppelwieser, V.G. (2014). Partial Least squares structural equation modeling (PLS-SEM): An Emerging tool in business research. European Business Review, 26, 106-121. https://doi.org/10.1108/EBR-10-2013-0128

Hakanen, J. J., Bakker, A. B., \& Schaufeli, W. B. (2006). Burnout and work engagement among teachers. Journal of School Psychology, 43(6), 495-513. https://doi.org/10.1016/j.jsp.2005.11.001

Hayes, A. F. (2013). Introduction to mediation, moderation, and conditional process analysis: A regression-based approach. New York City: Guilford Press.

Henseler, J., Ringle, C. M., \& Sarstedt, M. (2012). Using partial least squares path modeling in advertising research: basic concepts and recent issues. Handbook of Research on International Advertising, 252-267. https://doi.org/10.4337/9781781001042.00023

Henseler, J., Ringle, C. M., \& Sarstedt, M. (2015). A new criterion for assessing discriminant validity in variance-based structural equation modeling. Journal of the Academy of Marketing Science, 43(1), 115-135. https://doi.org/10.1007/s11747-014-0403-8

Hinduja, S. (2007). Neutralization theory and online software piracy: An empirical analysis. Ethics and Information Technology, 9(3), 187-204. https://doi.org/10.1007/s10676-007-9143-5

Hockey, G. R. J. (1997). Compensatory control in the regulation of human performance under stress and high workload: A cognitive-energetical framework. Biological Psychology, 45, 73-93. https://doi.org/10.1016/S0301-0511(96)05223-4

Houston, D., Meyer, L. H., \& Paewai, S. (2006). Academic staff workloads and job satisfaction: Expectations and values in academe. Journal of Higher Education Policy \& Management, 28(1), 17-30. https://doi.org/10.1080/13600800500283734 
Johnson, P. R., \& Indvik, J. (2001). Rudeness at work: Impulse over restraint. Public Personnel Management, 30, 457-466. https://doi.org/10.1177/009102600103000403

Jovanović, J., Lazaridis, K., \& Stefanović, V. (2006). Theoretical approaches to problem of occupational stress. Acta Facultatis Medicae Naissensis, 23(3), 163-169.

Kaplan, H. B. (1975). Self-attitudes and deviant behavior. New York: Good Year Publishing.

Karasek Jr, R. A. (1979). Job demands, job decision latitude, and mental strain: Implications for job redesign. Administrative Science Quarterly, 285-308. https://doi.org/10.2307/2392498

Theorell, T., \& Karasek, R. A. (1996). Current issues relating to psychosocial job strain and cardiovascular disease research. Journal of Occupational Health Psychology, 1(1), 9-22. https://doi.org/10.1037/1076-8998.1.1.9

Karasek, R. A., \& Theorell, T. (1990). Health work. New York: Basic Book.

Kura, K. M., Shamsudin, F. M., \& Chauhan, A. (2015). Does self-regulatory efficacy matter? Effects of punishment certainty and punishment severity on organizational deviance. SAGE Open, 5(2), 1-14. https://doi.org/10.1177/2158244015591822

Lawrence, T. B., \& Robinson, S. L. (2007). Ain't misbehavin: Workplace deviance as organizational resistance. Journal of Management, 33(3), 378-394. https://doi.org/10.1177/0149206307300816

Lim, S., Cortina, L. M., \& Magley, V. J. (2008). Personal and workgroup incivility: impact on work and health outcomes. Journal of Applied Psychology, 93(1), 95-107. https://doi.org/10.1037/0021-9010.93.1.95

Lim, V. K. (2002). The IT way of loafing on the job: cyberloafing, neutralizing and organizational justice. Journal of Organizational Behavior, 23(5), 675-694. https://doi.org/10.1002/job.161

Lim, V. K., \& Teo, T. S. (2009). Mind your E-manners: Impact of cyber incivility on employees' work attitude and behavior. Information and Management, 46(8), 419-425. https://doi.org/10.1016/j.im.2009.06.006

McCarthy, P., \& Mayhew, C. (2005). Occupational violence/bullying in public service organisations. Journal of Occupational Health and Safety, 21(1), 33-47.

Morris, R. G., \& Higgins, G. E. (2009). Neutralizing potential and self-reported digital piracy: A multi-theoretical exploration among college undergraduates. Criminal Justice Review, 34(2), 173-195. https://doi.org/10.1177/0734016808325034

Nasir, M., \& Bashir, A. (2012). Examining workplace deviance in public sector organizations of Pakistan. International Journal of Social Economics, 39(4), 240-253. https://doi.org/10.1108/03068291211205677

O'Brien, R. M. (2007). A caution regarding rules of thumb for variance inflation factors. Quality \& Quantity, 41(5), 673-690. https://doi.org/10.1007/s11135-006-9018-6 


\section{\Institute ${ }^{\text {Mach }}$}

International Journal of Human Resource Studies

ISSN 2162-3058

2017, Vol. 7, No. 4

Omar, Halim, Zainah, Farhadi, Nasir \& Kainidin. (2011). Stress and job satisfaction as antecedents of workplace deviant behavior. World Applied Sciences Journal, 12, 45-51.

Omolayo, O. B., \& Omole, C. O. (2013). Influence of mental workload on job performance. International Journal of Humanities and Social Science, 3(15), 238-246.

Podsakoff, P. M., MacKenzie, S. B., \& Podsakoff, N. P. (2012). Sources of method bias in social science research and recommendations on how to control it. Annual Review of Psychology, 63, 539-569. https://doi.org/10.1146/annurev-psych-120710-100452

Polit, D. F., \& Beck, C. T. (2006). The content validity index: are you sure you know what's being reported? Critique and recommendations. Research in Nursing \& Health, 29(5), 489-497. https://doi.org/10.1002/nur.20147

Preacher, K. J., \& Hayes, A. F. (2004). SPSS and SAS procedures for estimating indirect effects in simple mediation models. Behavior Research Methods, 36(4), 717-731. https://doi.org/10.3758/BF03206553

Preacher, K. J., \& Hayes, A. F. (2008). Asymptotic and resampling strategies for assessing and comparing indirect effects in multiple mediator models. Behavior Research Methods, 40(3), 879-891. https://doi.org/10.3758/BRM.40.3.879

Robinson, S. L. (2008). Dysfunctional orkplace behaviour. In J. Barling \& C. L. Cooper (Eds.), The Sage handbook of organizational behaviour (pp. 141-159). Thousand Oaks, CA: Sage

Robinson, S. L., \& Bennett, R. J. (1995). A typology of deviant workplace behaviors: A multidimensional scaling study. Academy of Management Journal, 38, 555-572. https://doi.org/10.2307/256693

Rogers, J. W., \& Buffalo, M. D. (1974). Neutralization techniques: Toward a simplified measurement scale. Pacific Sociological Review, 313-331. https://doi.org/10.2307/1388569

Rogerson, P.A. (2001). A statistical method for the detection of geographic clustering. Geography Anal 33(3), 215-227. https://doi.org/10.1111/j.1538-4632.2001.tb00445.x

Spector, P. E., \& Jex, S. M. (1998). Development of four self-report measures of job stressors and strain: Interpersonal conflict at work scale, organizational constraints scale, quantitative workload inventory, and physical symptoms inventory. Journal of Occupational Health Psychology, 3(4), 356-367. https://doi.org/10.1037/1076-8998.3.4.356

Spector, P.E. \& Fox, S. (2005). A model of counterproductive work behavior. In S. Fox and P.E. Spector (Eds.). Counterproductive work behaviour: Investigations of actors and targets (pp.151-174). Washington, DC: APA. https://doi.org/10.1037/10893-007

Stone, M. (1974). Cross-validatory choice and assessment of statistical predictions. Journal of the Royal Statistical Society. Series B (Methodological), 36, 111-147. https://doi.org/10.2307/2984809.

Stouten, J., Baillien, E., Van den Broeck, A., Camps, J., De Witte, H., \& Euwema, M. (2010). 


\section{Macrothink}

International Journal of Human Resource Studies

ISSN 2162-3058

2017, Vol. 7, No. 4

Discouraging bullying: The role of ethical leadership and its effects on the work environment. Journal of Business Ethics, 95, 17-27. https://doi.org/10.1007/s10551-011-0797-x

Sulaiman, M., \& Bhatti, O. K. (2013). Workplace deviance and spirituality in Muslim organizations. Asian Social Science, 9(10), 237-250.https://doi.org/10.5539/ass.v9n10p237

Sykes, G. M., \& Matza, D. (1957). Techniques of neutralization: A theory of delinquency. American Sociological Review, 22(6), 664-670. https://doi.org/10.2307/2089195

Taylor, S. G., Bedeian, A. G., \& Kluemper, D. H. (2012). Linking workplace incivility to citizenship performance: The combined effects of affective commitment and conscientiousness. Journal of Organizational Behavior, 33(7), 878-893. https://doi.org/10.1002/job.773

Yu, S. (2012). College students' justification for digital piracy: A mixed method study. Journal of Mixed Methods Research, 6, 364-378. https://doi.org/10.1177/1558689812451790

Yu, S. (2013). Digital piracy justification: Asian students versus American students. International Criminal Justice Review, 23(2), 185-196. https://doi.org/10.1177/1057567713485416

\section{Copyright Disclaimer}

Copyright for this article is retained by the author(s), with first publication rights granted to the journal.

This is an open-access article distributed under the terms and conditions of the Creative Commons Attribution license (http://creativecommons.org/licenses/by/4.0/). 